\title{
Assessment of building maintenance management practices of higher education institutions in Niger State - Nigeria
}

\author{
Ofide Blessing ${ }^{1}$, Jimoh Richard ${ }^{2 *}$ and Achuenu Emmanuel ${ }^{3}$ \\ ${ }^{1}$ Department of Quantity Surveying,Federal University of Technology, Minna-Nigeria \\ ${ }^{2}$ Department of Building, Federal University of Technology, Minna-Nigeria \\ ${ }^{3}$ Department of Building, University of Jos, Jos-Nigeria \\ * rosney@futminna.edu.ng
}

\begin{abstract}
Higher education institutions face immediate pressure to preserve existing building facilities within the campuses and enhance the capacity of their higher education system to address growing demands of an increasing influx of students and academic activities. There is no doubt that dilapidated and unhealthy buildings in a decaying environment depresses the quality of life and contributes in some measure to antisocial behaviours. The buildings of higher education institutions in Nigeria only receive top management attention when there is a problem. Hence, the paper assessed the building maintenance management practices of 6 higher institutions available ( 2 universities, 2 polytechnics and 2 colleges of education) in Niger State. This was done by interviewing the Directors of Works of the 6 institutions using a structured interview method. The study revealed that there was no maintenance manual in any of the Works Department of the higher education institution, no user satisfaction survey has ever been conducted and none of the institutions had a computerised maintenance management system (CMMS) in place. In addition to these, corrective maintenance was mostly adopted and there was inadequate staffing of the field operatives. All these shortcomings might be responsible for the backlog of maintenance work experienced in the institutions studied. A proactive maintenance system should be put in place, CMMS should be adopted to enhance effective maintenance work, and top management should be enlightened on the imperative of maintenance among other issues competing for funds within the institutions and be more flexible in allocation of resources to enhance maintenance works.
\end{abstract}

Keywords: maintenance, practices, higher education institutions, Niger State

\section{INTRODUCTION}

Buildings are an integral part of a nation's heritage, skyline and distinct character. They are designed and built to sustain their initial functions and beauty for both the present and future users. The condition and quality of buildings in which we live, work and learn reflects a nation's well-being (Wordsworth, 2001). According to Olagunju (2012), buildings cannot remain new throughout their entire life. Maintenance problems start to creep in once building projects are completed and maintenance needs to be carried out on them in order to sustain the performance of the buildings and keep them in good condition.

Higher education institution buildings constitute a significant part of the nation's assets. It is through the university buildings that, future leaders, captains of industry, entrepreneurs, professionals and scientists are produced (Mat et al., 2009). These types of buildings require maintenance in order to provide a quality and favourable environment for learning, research and administrative activities within the institution (Lateef, et al., 2010). Higher institutions these days among other things use the nature, design and condition of their buildings to entice students. The need for attractive facilities places new demands on maintenance managers, requiring them to adopt more systematic and pro-active approaches to their work (Buys \& Nkado, 2006). It has been established by Lateef et al. (2010) that, from time to time, new structures are being constructed within the various institutions to upgrade educational facilities and provide a better quality of education while the existing buildings suffer inadequate maintenance. Thus, with any inadequacy of the building facilities, the prime objective of the university will be difficult if not impossible to achieve (Lateef et al., 2010). Therefore, a well maintained building is critical to delivering higher education institutions core business objectives which includes learning, teaching and research. 
The growing population of students in higher education institutions is increasing on a yearly basis, therefore, it is important to ensure that buildings are performing not only optimally but are functional throughout their life-cycles. Hence, the educational process and learning activities may be interrupted if the buildings experience poor performance conditions, thus affecting the students' academic achievement (Khalil \& Husin, 2011). However, Buys et al. (2009) and Zulkarnain et al. (2011) indicated that the performance of tertiary institutions, in terms of maintenance management, is far below best practice. It can be seen that managers prefer carrying out reactive maintenance works rather than proactive works and sometimes do not consider the clients satisfaction and also the performance of services (Zulkarnain et al., 2011). A study carried out in Ghana showed that many of the public institutions in Ghana are often inadequately maintained and some of the building elements and facilities frequently show evidence of lack of maintenance and repair. Some of the office buildings of the institutions have not seen any significant maintenance or show little signs of maintenance since they were constructed. This lack of maintenance by the authorities and users of these facilities often leads to reduced lifespan of these buildings which invariably defeats the purpose for which they were constructed (Cobbinah, 2010). The situation in Nigeria is not in any way different from the Ghana scenario.

A considerable number of researches have been carried out on public and residential buildings (Adejimi, 2005; Adewunmi et al., 2011; Oladapo, 2004; Olagunju, 2012; Zubairu, 2001) with only a few on educational buildings. Studies have been conducted on educational building maintenance in South-western Nigeria and in other countries like Malaysia and South Africa. Buys and Nkado (2006) revealed inadequate funding as the most contributory factor to maintenance problems in South Africa higher institutions. In Akinsola et al. (2012), plumbing and electrical problems, and lack of maintenance culture are most peculiar to tertiary institutional buildings in South-western university buildings while Lateef et al. (2010) concluded that most Malaysian universities adopt corrective and cyclical maintenance management systems which led to an accumulation of maintenance backlogs. Since challenges abound in maintenance management practices of educational institutions highlighted above, and with the growing intake of students on these weakened building facilities, the aim of the study is to assess the building maintenance practices employed in higher education institutions in Niger State and suggest measures for effective maintenance management systems in these institutions. The paper reported a part of a 3-part study conducted in higher institutions in Niger State.

\section{CONCEPT OF BUILDING MAINTENANCE}

Building maintenance has consistently been treated as the "poor relation" of the construction industry, attracting only a tacit recognition of its importance, both within the industry and among building owners (Barrie $\&$ Peter, 2007). This manifest itself in a general lack of understanding of both its scope and its significance by all parties to the building procurement, construction and management processes. Therefore, the backlog of repair and maintenance work required to bring the country's building stock to a minimum acceptable level continues to grow to an unacceptable rate. Recently, the dimensions of maintenance problems have increased the interest of various professional researchers to promote an awareness of maintenance. This increasingly level of concern over the condition of the nation's building stock has served to expose more clearly the extent of the problem. Whilst effective maintenance policies are not by any means the norm, the efficient utilization of scarce resources is beginning to be approached in a more informed way and the fundamental relationship of the condition of a building's fabric to its total performance is examined more critically (Barrie \& Peter, 2007).

\section{MAINTENANCE MANAGEMENT PRACTICES}

Maintenance management is an orderly and systematic approach to planning, organizing, monitoring and evaluating maintenance activities and their costs (Technical Information Document (TID), 2000). A good maintenance management system coupled with knowledgeable and capable maintenance staff can prevent health and safety problems and environmental damage; yield longer assets life with fewer breakdowns and result in lower operating costs and higher quality of life for the occupants and users (Technical Information Document (TID), 2000).

There is a lot of work required to set up a successful maintenance management system. However, once it is in place, most of the data and calculations remain the same from year to year. The appropriate work orders and schedule must be revised and the labour, equipment, material and contract costs updated for the following year. There are numerous computerized maintenance management systems available in the commercial market to assist in effectively managing the maintenance of on-reserve assets. The maintenance supervisor or manager must also monitor the work progress daily, weekly or monthly depending on the nature of the situation and the potential 
impact of a service breakdown to the users. The maintenance manager must not wait until the year end to review the budget, as it would be too late to take any corrective action if it were necessary. The supervisor should determine the cause of the variance and, where possible, develop alternative solutions or actions to reduce time and costs. Taking these steps will help improve the efficiency and effectiveness of the maintenance programme (TID, 2000).

Maintenance management practices include the following;

1. Maintenance practices, such as preventive maintenance plan, work scheduled and standardization of activities - acceptable standard to which the building and its services are to be maintained.

2. A formal organizational plan chart with their maintenance records.

3. Response time required and acceptable in executing maintenance works - prioritisation of buildings e.g. between core and auxiliary functions.

4. The life (functional) requirements of the buildings and their fittings and services.

5. Maintenance funding system.

6. Training programme and staffing

7. A method of approval of work

8. Material requisition techniques

9. Quality assurance and

10. Maintenance strategies

\section{BUILDING MAINTENANCE DEPARTMENT}

According to Barrie and Peter (2007), maintenance departments are individuals liable for the organizing, scheduling and implementation of maintenance activities. Maintenance department in an organization is managed by a maintenance manager. This may be wholly in-house or, as is now much likely, may include independent bodies, such as consultants and contractors. In considering the maintenance management system to be used, the relationships with these bodies and the rest of the business organization must therefore be carefully taken into account. In a small firm, the functions may be undertaken by a member of staff in addition to his other duties, while in a larger firm there would be a separate group of people solely responsible for maintenance (Barrie \& Peter, 2007).

\subsection{MAINTENANCE DEPARTMENT AND STAFFING}

Organization and staffing are among the most crucial issues affecting maintenance works in the maintenance department (Wireman, 2005). Some organizations maintenance departments are structured based on work backlog. A maintenance backlog is the amount of work presently identified to be carried out by the maintenance department which is measured in hours (Wireman, 2005). When calculating the backlog, it is expedient to know the hours of maintenance work required and the current work force capacity. The formula for calculating backlog is given below:

Backlog $=$ identified work (in hours) $\div$ manpower capacity per week (in hours)

Backlog stems from the amount of emergency or corrective work that occurs on a weekly basis. In some institutions, emergency and corrective work makes up as much as $50 \%$ of the maintenance department's work distribution each week (Wireman, 2005). The technicians may also have routine assignments, meetings, absenteeism, vacations, and training that may contribute to the duration of time in executing a maintenance backlog. The maintenance department is staffed based on identified, not actual work. The volume of maintenance backlog to be carried out may not be executed within the specified duration if adequate resources are not available, in terms of man-power, funds and materials. The maintenance department would fall back to a corrective approach because current staff can never accomplish the required work in a proactive manner. It is regular practice for many companies to remove small jobs from the maintenance backlog or postponed to another time. Work should be identified and executed before it becomes critical to avoid backlog and increase in cost (Wireman, 2005).

\subsection{OUTSOURCING}

Outsourcing is a process whereby an organisation employs a separate company or supplier to perform a function that has previously been carried out in-house. This is often accompanied by a transfer of the works to the contractor or supplier of assets, including people and management responsibility (Barrie \& Peter, 2007).

The objective of outsourcing is for an organization to divest itself of non-core, peripheral functions in order to reduce costs in performing and managing what are considered low-priority operations. Associated with this is the prospect of improving efficiency through the use of specialist providers. Each organization may develop its own view as to the services it wishes to outsource, depending on its definitions of core business objectives (Barrie \& Peter, 2007).

\subsection{MAINTENANCE BUDGET}

A maintenance budget is a cost projection based on the costs of labour, equipment, material and other items 
(such as contracts) required to do all work identified in the Work Schedule (TID, 2000). A maintenance budget should identify the quantum of funding a department requires to adequately address the key maintenance needs of its buildings, to ensure that they continue to support the delivery of required services, to an acceptable standard identified in the organization's maintenance policy. Maintenance budget should be based on maintenance demand.

The distribution of funding for maintenance will be determined by factors such as organization's policy, asset management plan, the asset in question, current condition and age profile, operational requirements and backlog maintenance. The maintenance supervisor is responsible for monitoring the actual expenditures against the budget for the year. He or she is also responsible for its yearly update using forecast labour rates, and material and service contract costs. The updated budget would be used for determining the operation and maintenance costs of the building's physical assets. Maintenance personnel experience difficulties in determining the maintenance standard of a building because of the inadequate maintenance resources allocated from top management. Organizational and maintenance objectives are not properly understood at top management level; therefore allocation of maintenance resources is insufficient to meet maintenance needs. Building maintenance objectives has connections with core organizational objectives, and must be understood by the top management, strategic and operational level of management in order to improve the allocation of resources for maintenance needs. The personality of the maintenance manager and his dexterity come into play in giving maintenance budget its place through proper awareness to management of the importance of maintenance and its relationship with the organization's objectives; provided that the budget has bearing on the overall success of the organization.

\subsection{COMPUTERIZED MAINTENANCE MANAGEMENT SYSTEM (CMMS)}

Computerized maintenance management system (CMMS) is a type of management software that performs functions in support of management and tracking of maintenance activities (Lee \& Scott, 2009). CMMS promotes the management of building assets from conception through completion by tracking work request, scheduling work orders and reporting preventive maintenance tasks in great detail. It is used for improving building maintenance operation processes in terms of cost savings in labour and material, storing of maintenance procedures as well as all warranty information by component and storing of all technical documentation or procedures by component. CMMS can detect impending problems before a failure occurs resulting in fewer failures and users complaints, achieve a higher level of planned maintenance activities that enables a more efficient use of staff resources, affecting inventory control enabling better spare parts forecasting to eliminate shortages and minimize existing inventory, maintaining optimal equipment performance that reduces downtime and results in longer equipment life.

\section{METHODOLOGY}

The method adopted was structured interview. Structured interviews, according to Haigh (2008), involve the interviewer asking the interviewee a list of predetermined questions, hence, the same questions are asked from all the people that will be interviewed. This approach enhances the reliability of the results and the conclusions that will be reached, due to the standardisation of questions asked (Haigh, 2008). In a related development, Hesse-Biber and Leavy (2011) are of the opinion that standardising the interviews ensures comparisons to be made between the interviewees. As a result of the above reasons, as advanced by Haigh (2008) and Hesse-Biber and Leavy (2011), the approach adopted for the interview sessions was the structured interview with both closed and open ended questions. In determining the number of institutions, purposive sampling was used. This sampling technique is a nonprobability sampling procedure which is usually used in qualitative research that has to do with selecting the people to be interviewed based on the interviewer's knowledge on the appropriateness and typicality of the sample selected (Cohen et al., 2005; David \& Sutton, 2004).

The Directors of Maintenance Works Department of the 2 Universities, the 2 Polytechnics and the 2 Colleges of Education in Niger State were interviewed. The interviews were tape recorded with the consent of the interviewees and each interview lasted for and an average of 30 minutes. It should be noted that there were only 2 Universities, 2 Polytechnics and 2 Colleges of Education in the State; hence, it was the population that was used. The data obtained were analysed using content analysis. The maintenance practices discussed in this study were in the areas of funding, maintenance records, materials and nature of maintenance works, quality assurance, maintenance strategy, training/staffing, challenges/measures. These formed the basis for the conclusion and the suggestions made. The paper is part of a study on maintenance practices of higher institutions in Niger State-Nigeria. 


\section{RESULTS AND DISCUSSION}

Table 1 shows the frequency analysis of maintenance practices with respect to funding in the various higher institutions. $83.3 \%$ of the maintenance directors affirmed that they have maintenance budgets in their various higher institutions, while only $16.6 \%$ did not have a maintenance budget. It was also observed that the budget is in form of a short-term budget, which attributed for $50 \%$ of the interviewed directors of maintenance works. The table also revealed that, it takes mostly between $0-3$ months for funds to be approved for maintenance works which accounted for $83.3 \%$. The estimated budget ranges from 50 million naira and above which accounted for $50 \%$, while the other $50 \%$ was between $5-50$ million naira. The study also found out that funds are released occasionally, only one of the directors confirmed that funds are released as occasion demands, which accounted for only $16.7 \%$. The study further found out that the funds released are not sufficient to meet the maintenance needs of the higher education institution, which accounted for $100 \%$ of the respondents. The funds for maintenance works are not provided as and when due hence delays are experienced in carrying out the work, further deterioration of building components and additions to maintenance backlogs. This is in line with Lateef et al. (2010) who stated that maintenance is budget-driven and not need-driven. Maintenance is only carried out subject to availability of funds which automatically puts off cyclical maintenance until when funds are available to perform the tasks.

Table 1: Frequency analysis of maintenance practices of funds in higher education institutions

\begin{tabular}{|c|c|c|c|c|}
\hline Practice Codes & Maintenance Practices & Options & Frequency & Percent \% \\
\hline \multirow[t]{21}{*}{ FUNDS } & $\begin{array}{l}\text { Does the higher institution have a } \\
\text { budget for maintenance works? }\end{array}$ & Yes & 5 & 83.3 \\
\hline & & No & 1 & 16.7 \\
\hline & & Total & 6 & 100.0 \\
\hline & The budget is in form of; & Long term budget & 1 & 16.7 \\
\hline & & Medium term budget & 1 & 16.7 \\
\hline & & Short term budget & 3 & 50.0 \\
\hline & & None & 1 & 16.7 \\
\hline & & Total & 6 & 100.0 \\
\hline & $\begin{array}{l}\text { How long does it take to approve } \\
\text { funds for maintenance works? }\end{array}$ & 0 - 3 months & $\begin{array}{l}5 \\
1\end{array}$ & $\begin{array}{l}83.3 \\
167\end{array}$ \\
\hline & & $\begin{array}{l}6 \text { months - } 1 \text { year } \\
\text { Total }\end{array}$ & $\frac{1}{6}$ & $\begin{array}{r}16.7 \\
1000\end{array}$ \\
\hline & What is the range of estimated annual & 5 - 10 million naira & 1 & 16.7 \\
\hline & maintenance budget for the higher & 21 - 30 million naira & 1 & 16.7 \\
\hline & institution? & $31-50$ million naira & 1 & 16.7 \\
\hline & & 50 million and above & 3 & 50.0 \\
\hline & & Total & 6 & 100.0 \\
\hline & How are funds released? & Quarterly & 5 & 83.3 \\
\hline & & as occasion demands & 1 & 16.7 \\
\hline & & Total & 6 & 100.0 \\
\hline & How are the funds generated? & $\begin{array}{l}\text { The higher institution releases } \\
\text { funds for maintenance works } \\
\text { Internal generated revenue }\end{array}$ & $\begin{array}{l}5 \\
1\end{array}$ & $\begin{array}{l}83.3 \\
16.7\end{array}$ \\
\hline & & Total & 6 & 100.0 \\
\hline & $\begin{array}{l}\text { Are the funds sufficient to meet the } \\
\text { maintenance needs of the higher } \\
\text { institution? }\end{array}$ & No & 6 & 100.0 \\
\hline
\end{tabular}


Table 2: Frequency analysis of maintenance practices of maintenance records, materials and nature of maintenance works in higher education institutions

\begin{tabular}{|c|c|c|c|c|}
\hline Practice Codes & Maintenance Practices & Options & Frequency & $\begin{array}{c}\text { Percent } \\
\%\end{array}$ \\
\hline \multirow{4}{*}{$\begin{array}{l}\text { MAINTENANCE } \\
\text { RECORDS }\end{array}$} & How do you keep & & & \\
\hline & maintenance records? & receipts/invoices/filing system & 5 & 83.3 \\
\hline & & book keeping & 1 & 16.7 \\
\hline & & Total & 6 & 100.0 \\
\hline \multirow[t]{3}{*}{ MATERIALS } & $\begin{array}{l}\text { What technique do you adopt } \\
\text { in requisition of materials for } \\
\text { maintenance work? }\end{array}$ & buy only when needed & 5 & 83.3 \\
\hline & & buy in bulk and store & 1 & 16.7 \\
\hline & & Total & 6 & 100.0 \\
\hline $\begin{array}{l}\text { NATURE OF } \\
\text { MAINTENANCE }\end{array}$ & $\begin{array}{l}\text { What type of repairs have you } \\
\text { mostly carried out in the past }\end{array}$ & & & \\
\hline \multirow[t]{6}{*}{ WORKS } & 5years? & Minor & 2 & 33.3 \\
\hline & & both minor and major & 4 & 66.7 \\
\hline & & Total & 6 & 100.0 \\
\hline & What is the most occurred & repairs and renovation & 2 & 33.3 \\
\hline & $\begin{array}{l}\text { nature of maintenance work } \\
\text { on building components } \\
\text { affected within the higher }\end{array}$ & $\begin{array}{l}\text { repairs and replacement } \\
\text { repairs, replacement, } \\
\text { renovation, refurbishment and }\end{array}$ & 1 & 16.7 \\
\hline & 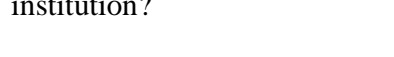 & $\begin{array}{l}\text { extension } \\
\text { Total }\end{array}$ & $\frac{3}{6}$ & $\frac{50.0}{100.0}$ \\
\hline
\end{tabular}

Table 3: Frequency analysis of maintenance practices of quality assurance in higher education institutions

\begin{tabular}{|c|c|c|c|c|}
\hline Practice Codes & Maintenance Practices & Options & Frequency & Percent $\%$ \\
\hline \multirow{21}{*}{$\begin{array}{l}\text { QUALITY } \\
\text { ASSURANCE }\end{array}$} & \multirow{8}{*}{$\begin{array}{l}\text { Which of the users can make } \\
\text { complaints to the maintenance } \\
\text { dept? }\end{array}$} & school secretary/faculty & & \\
\hline & & officer/hall officer & 2 & 33.3 \\
\hline & & school secretary/faculty & 1 & \\
\hline & & & 1 & 16.7 \\
\hline & & staffs and students & 2 & 33.3 \\
\hline & & $\begin{array}{l}\text { head of department and school } \\
\text { secretary/faculty officer/hall }\end{array}$ & & \\
\hline & & officer & 1 & 16.7 \\
\hline & & Total & 6 & 100.0 \\
\hline & \multirow{6}{*}{$\begin{array}{l}\text { What are the various } \\
\text { complaint mechanisms? }\end{array}$} & write memo & 1 & 16.7 \\
\hline & & Telephone & 1 & 16.7 \\
\hline & & $\begin{array}{l}\text { job requisition cards/forms } \\
\text { write memo and job requisition }\end{array}$ & 1 & 16.7 \\
\hline & & cards/forms & 1 & 16.7 \\
\hline & & telephone and write memo & 2 & 33.3 \\
\hline & & Total & 6 & 100.0 \\
\hline & \multirow{3}{*}{$\begin{array}{l}\text { What is the frequency of } \\
\text { complaints from users of the } \\
\text { building facilities? }\end{array}$} & very often & 5 & 83.3 \\
\hline & & Regular & 1 & 16.7 \\
\hline & & Total & 6 & 100.0 \\
\hline & \multirow{4}{*}{$\begin{array}{l}\text { Which of the users do you } \\
\text { receive the most maintenance } \\
\text { complaints from? }\end{array}$} & Students & 3 & 50.0 \\
\hline & & staff & 2 & 33.7 \\
\hline & & students and staff & 1 & 16.7 \\
\hline & & Total & 6 & 100.0 \\
\hline
\end{tabular}




\begin{tabular}{|c|c|c|c|}
\hline $\begin{array}{l}\text { What is the ranking of the } \\
\text { Maintenance Works } \\
\text { Department in carrying out } \\
\text { maintenance problems? }\end{array}$ & Average & 6 & 100.0 \\
\hline $\begin{array}{l}\text { Have you conducted any user } \\
\text { satisfaction survey? }\end{array}$ & No & 6 & 100.0 \\
\hline $\begin{array}{l}\text { Do you follow a quality } \\
\text { assurance programme that } \\
\text { includes the use of } \\
\text { maintenance standards? }\end{array}$ & $\begin{array}{l}\text { Yes } \\
\text { No } \\
\text { Total }\end{array}$ & $\begin{array}{l}1 \\
5 \\
6\end{array}$ & $\begin{array}{r}16.7 \\
83.3 \\
100.0\end{array}$ \\
\hline $\begin{array}{l}\text { Do you follow a quality } \\
\text { assurance programme that } \\
\text { includes the use of } \\
\text { monitoring? }\end{array}$ & No & 6 & 100.0 \\
\hline $\begin{array}{l}\text { Do you follow a quality } \\
\text { assurance programme that } \\
\text { includes the use of inspecting } \\
\text { and evaluating completed } \\
\text { works? }\end{array}$ & Yes & 6 & 100.0 \\
\hline $\begin{array}{l}\text { Do you follow a quality } \\
\text { assurance programme that } \\
\text { includes the use of developing } \\
\text { corrective action plan? }\end{array}$ & Yes & 6 & 100.0 \\
\hline \multirow[t]{2}{*}{$\begin{array}{l}\text { Is the maintenance department } \\
\text { consulted during contract } \\
\text { stage of new building projects } \\
\text { within the higher education } \\
\text { institution? }\end{array}$} & $\begin{array}{l}\text { Yes } \\
\text { No }\end{array}$ & $\begin{array}{l}3 \\
3\end{array}$ & $\begin{array}{l}50.0 \\
50.0\end{array}$ \\
\hline & Total & 6 & 100.0 \\
\hline $\begin{array}{l}\text { Do you have a maintenance } \\
\text { manual for your higher } \\
\text { institution? }\end{array}$ & No & 6 & 100.0 \\
\hline
\end{tabular}

Table 2 shows the maintenance practices with respect to maintenance records, materials, and the nature of maintenance works carried out. It revealed that $83.3 \%$ of the maintenance departments kept their maintenance records using receipts/invoices/filling system, while $16.7 \%$ kept their records using book keeping system. Some of the receipts are not properly kept and documented, some records for past maintenance works of the last ten years are not in place. In requisitioning of maintenance materials, $83.3 \%$ of the maintenance departments in the various HEI only buy materials when needed, while $16.7 \%$ buy in bulk and store them until needed. The major types of repairs that have mostly been carried out in the past 5 years on the HEI buildings are both minor and major repairs $(66.7 \%)$. The minor works are carried out by in-house maintenance staff while the major works are contracted out. Some of the major works are carried out every 4 years, or when there is an accreditation from the Regulatory Agencies such as the National Universities Commission (NUC), the National Board for Technical Education (NBTE) and
National Board for Colleges of Education and during the year of convocation ceremony, or when management releases funds for massive maintenance works and renovations. The study further revealed that the nature of maintenance works mostly carried out were repairs which were common to all the higher education institutions studied.

Table 3 illustrates maintenance practices in the various higher education institutions regarding quality assurance. It was observed that the users that can make complaints to the maintenance departments are school secretary/faculty officer/hall officer, staff and students which accounted for $33.3 \%$ each. The various complaint mechanisms are telephone and memo (33.3\%) which could be found in four of the HEI studied while job requisition cards/forms (16.7\%) were found in the remaining two higher education institutions. The frequency of complaints from users of the building facilities is also very often (83.3\%). The table also revealed that students make the most 
complaints to the maintenance department $(66.7 \%)$, which was seen in four of the higher institutions. Two of the higher education institutions showed that workers also make complaints (49.4\%). The response rate of the Maintenance Works Department to execute maintenance problems is average and accounted for $100 \%$ of the respondents. The study also found out that a user satisfaction survey has never been conducted by the maintenance department in any of the six (6) higher education institutions studied. This could be attributed to the dominance of reactive maintenance approaches. This is in line with the findings of Adewunmi et al. (2009) and Lateef et al. (2010). Feedback mechanisms from the users would serve as a basis for meaningful performance measurement and maintenance management. Since users are the direct beneficiaries of these facilities, they are the only people who can define the quality of services they are receiving. It was also found out that the majority of the higher education institutions maintenance department do not follow a quality assurance programme that includes the use of maintenance standards $(83.3 \%)$. Only one higher education institution follows this particular programme (16.7\%). All the higher education institutions do not follow a quality assurance programme that includes the use of monitoring $(100 \%)$. However, it was found that all the higher education institutions do follow a quality assurance programme that includes the use of inspecting and evaluating completed works and developing corrective action plans which accounted for $100 \%$ of the total respondents respectively. $50 \%$ of the respondents in three of the higher education institutions affirmed that the maintenance department is consulted during contract stage of new building projects within the HEI, while the other $50 \%$ in the other three higher education institutions are not consulted. It is after the project has been completed that maintenance staff are to check for building defects. The implication of this is that shoddy jobs would have been covered up by then which could lead to large sums of money to be spent in maintenance work. None of the institutions had maintenance manual in place $(100 \%)$.

Table 4 shows the maintenance practices in the various higher education institutions with respect to maintenance strategy. The table showed that there is maintenance policy in place in three higher education institutions $(50 \%)$ while the other three had no maintenance policy (50\%). Maintenance is mostly carried out when the need arises $(50 \%)$, while every month, every year and when the need arises and every 4 years accounted for $16 \%$ each. The table also revealed that almost all the six (6) HEI adopt corrective maintenance approaches for their maintenance works $(83.3 \%)$, while only one higher education institution adopted both corrective and routine maintenance approaches (16.7\%). Components fail before they are replaced or maintained. This is due to over dependence on funds available for maintenance works and maintenance is carried out only when users make complaints. This result supports the findings of Buys and Nkado (2006) and Lateef et al. (2011). It was also revealed that the higher education institutions adopted correct maintenance system approaches because cost is saved when maintenance works are quickly executed and management easily releases funds when funds are not large for accumulated maintenance works. Time is saved when problems are corrected quickly unlike in planned maintenance systems and components will take lesser time to further deteriorate and increased expenses in the long run is saved. The quality of components is improved because better materials are used to replace defective components or improve on them. Hence, end users are safe to quickly use facilities and properties are protected unlike in the case of planned maintenance. This accounted for $100 \%$ of the respondents as these reasons were seen to be similar in all the higher education institutions. The study also revealed that building condition surveys have only been carried out in hostel buildings of four higher education institutions and this survey is only carried out once in a year on the hostel buildings (66.7), while the other two studied higher education institutions have never carried out any building condition survey (33.3\%). Building condition surveys are only carried out on hostel buildings at the end of every session when students are home for the long break. The maintenance departments then maintain some of the damaged building components before the commencement of a new session for the students. However, no building condition survey has ever been performed on academic buildings. The maintenance staff in place are not enough to meet the demand of maintaining works and at the same time evaluating buildings. The maintenance departments are necessitated to carry out maintenance works which are mainly based on requests from the users of the buildings $(18.3 \%$ ), while $16.7 \%$ is based on request from the users of the buildings and building inspections. Buildings defects are checked mostly when users report defects and then maintenance staff rectify the defects $(83.3 \%$ ), while $16.7 \%$ is based on users reporting defects then maintenance staff rectify the defects and maintenance staff inspects regularly and report defects for rectification. Maintenance works is majorly carried out through both in-house and outsourcing in all six higher education institutions $(100 \%)$. This finding is in line with conclusions from Lateef et al. (2011) that most minor repairs are carried 
out by in-house staff while major maintenance works are outsourced. The major procurement strategy for contract maintenance works is mainly by nomination which was evident in three institutions. The other three higher education institutions procure maintenance contracts through job order, selective, job order and nomination, selective and nomination (16\% each).

Table 4: Analysis of maintenance practices of maintenance strategy in higher education institutions

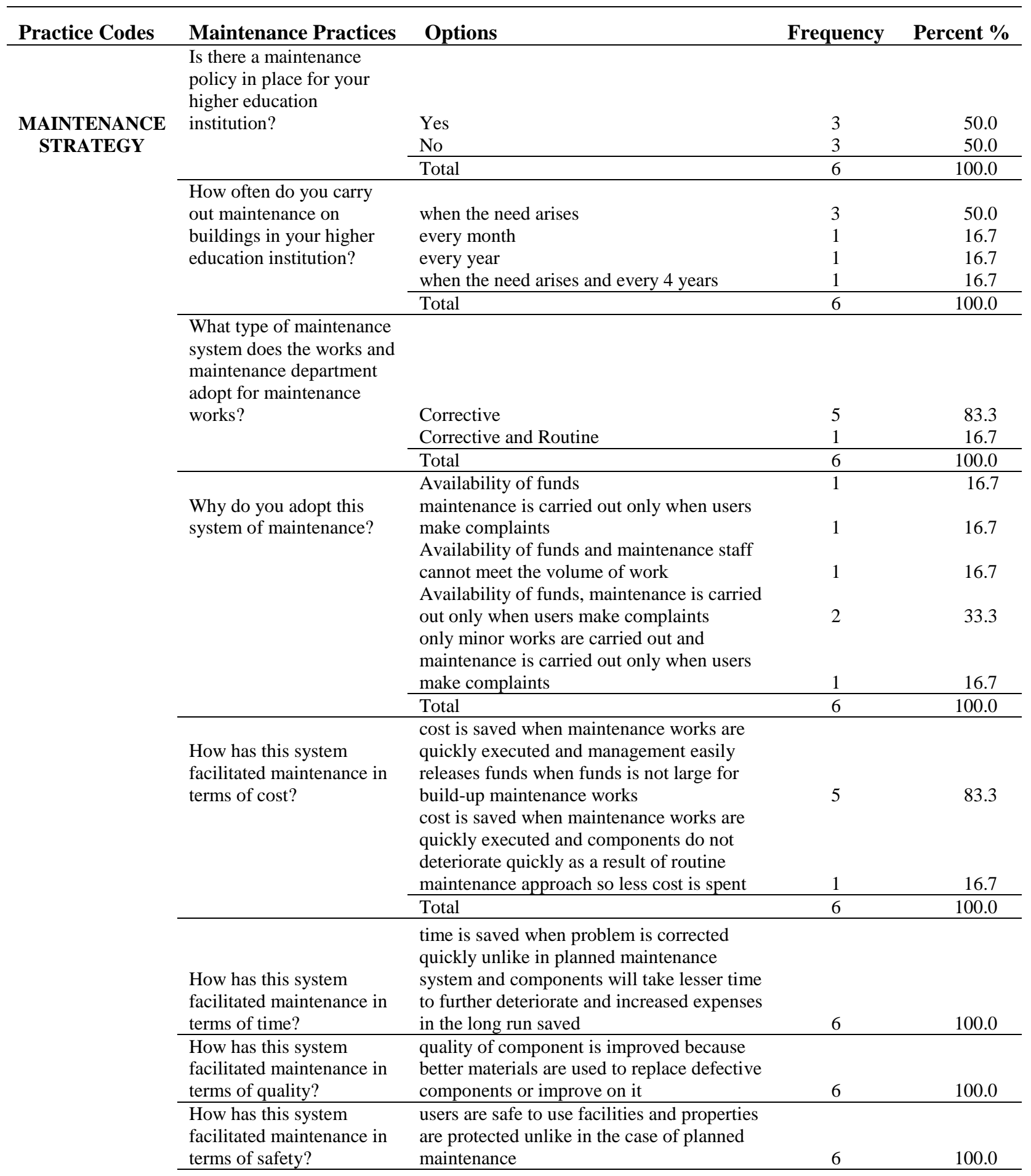


Do you carry out building condition survey on the institutional buildings?

only on hostel buildings

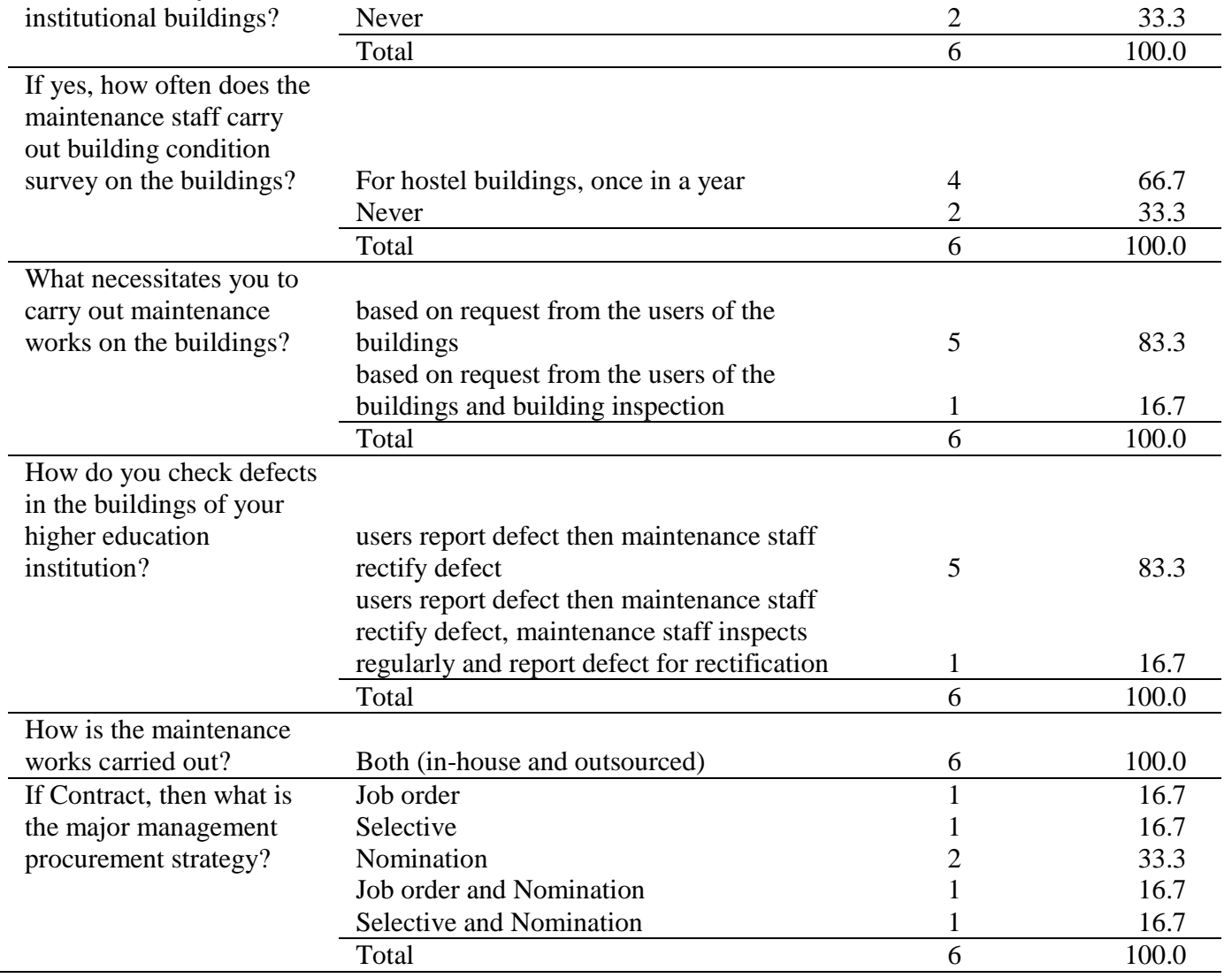

Table 5: Frequency analysis of maintenance practices of training/staffing in higher education institutions

\begin{tabular}{|c|c|c|c|c|}
\hline Practice Codes & Maintenance Practices & Options & Frequency & Percent \% \\
\hline \multirow[t]{13}{*}{$\begin{array}{l}\text { TRAINING / } \\
\text { STAFFING }\end{array}$} & $\begin{array}{l}\text { Are the numbers of tradesmen } \\
\text { adequate to meet the volume of } \\
\text { maintenance work? } \\
\text { Do you receive training on } \\
\text { building maintenance }\end{array}$ & No & 6 & 100.0 \\
\hline & management? & Yes & 4 & 66.7 \\
\hline & & No & 1 & 16.7 \\
\hline & & yes but only director of works & 1 & 16.7 \\
\hline & & Total & 6 & 100.0 \\
\hline & $\begin{array}{l}\text { If yes, what type of training is } \\
\text { being put in place for staff skill }\end{array}$ & $\begin{array}{l}\text { seminar/conferences } \\
\text { seminar/conferences and }\end{array}$ & 4 & 66.7 \\
\hline & improvement? & certified professional courses & 1 & 16.7 \\
\hline & & Never & 1 & 16.7 \\
\hline & & Total & 6 & 100.0 \\
\hline & How regular is the training held & Quarterly & 4 & 66.7 \\
\hline & for the maintenance staffs? & once in a year & 1 & 16.7 \\
\hline & & Never & 1 & 16.7 \\
\hline & & Total & 6 & 100.0 \\
\hline
\end{tabular}


Table 6: Frequency analysis of maintenance practices of maintenance challenges/measures in higher education institutions

\begin{tabular}{|c|c|c|c|c|}
\hline Practice Codes & Maintenance Practices & Options & Frequency & Percent \% \\
\hline \multirow[t]{18}{*}{$\begin{array}{l}\text { MAINTENANCE } \\
\text { CHALLENGES / } \\
\text { MEASURES }\end{array}$} & $\begin{array}{l}\text { What is the attitude of } \\
\text { students to the building } \\
\text { facilities provided in the } \\
\text { higher education institution? }\end{array}$ & Poor & 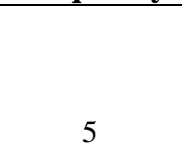 & 83.3 \\
\hline & & Fair & 1 & 16.7 \\
\hline & & Total & 6 & 100.0 \\
\hline & $\begin{array}{l}\text { What is the attitude of staff to } \\
\text { the building facilities } \\
\text { provided in the higher } \\
\text { education institution? }\end{array}$ & Fair & 6 & 100.0 \\
\hline & & Electrical, plumbing and roof & 2 & 33.3 \\
\hline & & Plumbing, windows and doors & 1 & 16.7 \\
\hline & $\begin{array}{l}\text { Which defect is most } \\
\text { observed on the buildings? }\end{array}$ & & 1 & 16.7 \\
\hline & & & 1 & 16.7 \\
\hline & & Electrical, plumbing and structural & 1 & 16.7 \\
\hline & & Total & 6 & 100.0 \\
\hline & $\begin{array}{l}\text { What are the challenges being } \\
\text { faced by the maintenance } \\
\text { department in effective } \\
\text { maintenance management } \\
\text { delivery in the higher }\end{array}$ & $\begin{array}{l}\text { Inadequate funds } \\
\text { Inadequate funds, shortage of staffs } \\
\text { (professional \& tradesmen), users } \\
\text { delay in reporting maintenance } \\
\text { problems, electrical power }\end{array}$ & 1 & 16.7 \\
\hline & education institution? & $\begin{array}{l}\text { fluctuation } \\
\text { Inadequate funds, shortage of staffs }\end{array}$ & 1 & 16.7 \\
\hline & & $\begin{array}{l}\text { (professional \& tradesmen) } \\
\text { (professionale funds, shortage of staffs } \\
\text { maintenance culture/misuse of }\end{array}$ & 2 & 33.3. \\
\hline & & $\begin{array}{l}\text { building facilities by users } \\
\text { Inadequate funds, bottlenecks / }\end{array}$ & 1 & 16.7 \\
\hline & & loopholes in management & 1 & 16.7 \\
\hline & & Total & 6 & 100.0 \\
\hline & $\begin{array}{l}\text { How can the above stated } \\
\text { challenges be minimized? }\end{array}$ & $\begin{array}{l}\text { Prompt availability/improved } \\
\text { funding system, employment of } \\
\text { qualified maintenance personnel, } \\
\text { improved communication between } \\
\text { maintenance department and users, } \\
\text { maintenance awareness to } \\
\text { management and users, build more } \\
\text { hostels/reduce overcrowding of } \\
\text { offices and hostel rooms } \\
\text { Prompt availability/improved } \\
\text { funding system, employment of } \\
\text { qualified maintenance personnel, } \\
\text { maintenance awareness to } \\
\text { management and users }\end{array}$ & 1 & 16.7 \\
\hline & & management and users & 1 & 16.7 \\
\hline
\end{tabular}


Prompt availability/improved

funding system, build more

hostels/reduce overcrowding of

offices and hostel rooms, payment of

fee to hold accountable any user that

violates maintenance policy/rules

Prompt availability/improved

funding system, maintenance

awareness to management and users,

research and training of maintenance

staff

Prompt availability/improved

funding system, employment of qualified maintenance personnel, incentives to motivate maintenance staffs for effective maintenance delivery

Prompt availability/improved funding system, maintenance

awareness to management and users

Table 5 illustrates the frequency analysis of maintenance practices in the six (6) higher education institutions regarding training / staffing. It was shown that the numbers of tradesmen are not adequate to meet the volume of maintenance works $(100 \%)$. The maintenance departments cannot function properly without adequate maintenance staff to handle the magnitude of maintenance problems which are overwhelming. This finding supports that of Buys and Nkado (2006). The table further revealed that four of the higher education institution's maintenance departments receive training on building maintenance management $(66.7 \%)$, one of the higher institution do not receive any training $(16.67 \%)$, while in the last higher institution, only the maintenance director receive maintenance management training but the staff do not $(16.67 \%)$. The type of training received is mostly at seminars/conferences which was seen to be mostly attended by the maintenance staff in five of the higher education institutions. The trainings are usually held quarterly in most of the higher education institutions $(66.7 \%)$, while once in a year accounted for $16.7 \%$. They however do not undergo management programmes and other certified courses. They do not have opportunities to attend international conferences/seminars except the maintenance directors. The maintenance staff are limited and restricted in their knowledge base for advanced and technological maintenance systems and innovations as adopted in other higher education institutions of developed countries.
Table 6 above shows the maintenance practices in the various higher education institutions with respect to maintenance challenges / measures. The table showed that the attitude of students to the building facilities provided in the higher institution is mostly poor $(83.3 \%)$. Maintenance Staff are therefore faced with the problem of managing students who misuse these facilities and overcrowd the required hostel and lecture spaces for the intended number of usage. The attitude of staff to the building facilities provided in the all higher education institutions is fair (100\%). The defects mostly observed on the buildings in the various higher education institutions are electrical, plumbing and roof problems. This is in line with condition survey assessment of the buildings and the secondary data provided on past works of maintenance carried out in the last five years. The challenges being faced by the maintenance department in effective maintenance management delivery in the higher education institutions are mainly inadequate funds, shortage of staff (professional and tradesmen) which accounted for $33.3 \%$ of the total respondents. These problems were evident in almost all the higher education institutions. Inadequate funds, shortage of staffs (professional and tradesmen), lack of maintenance culture/misuse of building facilities by users, inadequate funds, shortage of staff (professional and tradesmen), users delay in reporting maintenance problems, electrical power fluctuation, bottlenecks / loopholes in management were significant in other higher education institutions and accounted for $16.7 \%$ each. These challenges could be minimized by prompt availability/improved funding system, employment of 
qualified maintenance personnel, improved communication between maintenance departments and users, maintenance awareness of management and users, build more hostels/reduce overcrowding of offices and hostel rooms (16.7\%), prompt availability/improved funding system, employment of qualified maintenance personnel, maintenance awareness to management and users (16.7\%), build more hostels/reduce overcrowding of offices and hostel rooms, payment of fee to hold accountable any user that violates maintenance policy/rules (16.7\%), research and training of maintenance staff (16.7\%), employment of qualified maintenance personnel, incentives to motivate maintenance staff for effective maintenance delivery $(16.7 \%)$, maintenance awareness to management and users (16.7\%).

\section{CONCLUSION}

The majority of building problems in the study area stem from management-related problems, and users' misuse of building facilities and faulty workmanship. The components with the most encountered problems are electrical and plumbing which have been on the rise and will continue to be so if adequate considerations are not given to contain it. Hostel buildings are given lesser maintenance priorities than offices and lecture halls. The majority of the users use hostel spaces more than other building types. Since these hostel facilities are in poor condition, students may face health challenges, which could result in them not being productive in the poor environment. The poor condition of buildings in this environment therefore has a direct relationship with the performance of the users of these facilities provided by the institutions. It was also concluded that all higher education institutions in the area adopted corrective maintenance approaches; no user satisfaction survey is conducted. The maintenance backlog and shortage of maintenance personnel to meet the maintenance needs could be the reason why the institutions adopted corrective maintenance. Another important area overlooked by the Works Department of the institutions was the user satisfaction survey that had never been conducted before. From the way records were kept, there was no computerized maintenance management system in place. Since management delay in meeting the demand of the maintenance department, maintenance staff are also faced with inadequate supply of funds; building components further deteriorate, causing harm to the users and an unproductive environment for learning, research and administrative activities.

In order to improve the maintenance management of these institutions, the following are suggested; i. A proactive system of maintenance should be adopted by the higher institutions for effective maintenance management so that the life of the building assets could be prolonged.

ii. A building maintenance manual should be provided by the higher institution to the maintenance departments and the users of the building facilities.

iii. A yearly building condition survey should be carried out on all buildings.

iv. Top management to be more interested in maintenance needs and a more structured and planned budgeting system should be put in place to allocate funds early for maintenance needs.

v. Awareness of both users and top management on maintenance culture.

vi. Employment of qualified personnel and skilled tradesmen to meet the volume of maintenance backlogs. The current maintenance staff should also be given incentives to motivate them to work harder.

vii. A computerized maintenance management system (CMMS) should be put in place for effective maintenance management and keeping data bank maintenance records.

\section{REFERENCES}

Adejimi, A. (2005). Poor building maintenance in Nigeria; Are architects free from blame? Presented paper, ENHR International conference, Iceland. Retrieved December 15, 2012, from http://www.goggle.arayela.

Adewunmi, Y., Famuyiwa, F., \& Harrison, E. (2009). Post occupancy evaluation of hostel facilities in Nigerian private universities: A case study. In A. Dainty (Ed.), Proceedings of 25th Annual ARCOM Conference, 7-9 September 2009 (505 - 514), Nottingham, UK: Association of Researchers in Construction Management.

Adewunmi, Y., Omirin, M., Famuyiwa, F., \& Farinloye, O. (2011). Post-occupancy evaluation of post graduate hostel facilities. Facilities, 29(3), 149 - 168.

Akinsola, O.E., Hussaini, P.O., Oyenuga, S.O., \& Fatokun, A.O. (2012). Critical factors influencing facility maintenance management of tertiary institutional buildings in South West Nigeria. Mediterranean Journal of Social Sciences, 3(11), $489-496$. 
Barrie, C., \& Peter, S. (2007). Building maintenance management (2nd ed.). Oxford, United Kingdom: Blackwell Publishing.

Buys, F., \& Nkado, R. (2006). A survey of approaches to maintenance management in tertiary institutions in South Africa. Construction Management and Economics, 24, 997 - 1005.

Buys, F., Cumberledge, R., \& Crawford, G. (2009). Comparative analysis of the performance of tertiary institutions in managing its assets. RICS COBRA Research Conference (pp. 658-671). University of Cape Town, 10-11th September 2009.

Cobbinah, P.J. (2010). Maintenance of buildings of public institutions in Ghana. Case study of selected institutions in the Ashanti region of Ghana (Unpublished Msc Thesis). Department of Planning, Kwame Nkrumah University of Science and Technology, Kumasi, Ghana.

Cohen, L., Manion, L., \& Morrison, K. (2005). Research methods in education (5th ed.). London: Taylor \& Francis e-library.

David, M., \& Sutton, C.D. (2004). Social research: The basics $\left(1^{\text {st }}\right.$ ed.). California: Sage Publications Inc.

Haigh, R. (2008). Interviews: A negotiated partnership. In A. Knight. \& L. Ruddock, Advanced research methods in the built environment. UK: Wiley-Blackwell Publishing Limited.

Hesse-Biber, S.N., \& Leavy, P. (2011). The practice of qualitative research (2nd ed.). US: Sage.

Khalil, N., \& Husin, H.N. (2011).Sustainable building rating tool towards learning improvement in Malaysia's higher institution: A proposal. International Conference on Social Science and Humanity, 5. IACSIT Press, Singapore.

Lateef, O A, Khamidi, M. F., \& Idrus, A. (2010). Building maintenance management in a Malaysian university campuses: A case study. Australasian Journal of Construction Economics and Building, 10(1/2), 76-89.

Lee, H.H., \& Scott, D. (2009). Overview of maintenance strategy, acceptable maintenance standard and resources from a building maintenance operation perspective.
Journal of Building Appraisal, 4(4), 269 278.

Mat, S., Sopian, K., Moktar, M., Hashim, S.H., Abdul R.A., Zain, M.F.M., \& Abdullah, G.N. (2009). Managing sustainable campus in Malaysia - Organizational approach and measures. European Journal of Social Science, 8(2), 201- 214.

Oladapo, A. A. (2004). A comparative evaluation of the building maintenance management of three tertiary educational institutions in Osun State. Journal of Property Research and Construction, 1, 1-13.

Olagunju, R.E. (2012). Predictive modelling for sustainable residential building maintenance in developing countries: A Nigerian case. Interdisciplinary Journal of Contemporary Research in Business, 4(6), 1273 - 1274.

Technical Information Document (2000). Maintenance management systems. RPS for INAC. Retrieved from, http://publications.gc.ca/collections/Collecti on/P25-5-2-2000E.pdf

Wireman, T. (2005). Developing performance indicators for managing maintenance $\left(2^{\text {nd }}\right.$ Ed.). New York: Industrial Press Inc.

Wordsworth, P. (2001). Lee's building maintenance management. ( $4^{\text {th }}$ Ed.). Oxford. Blackwell Science Ltd.

Zubairu, S. N. (2001). A model process for maintenance planning and operations, Journal of Association of Architectural Educators in Nigeria, 1(6), 1 - 7 .

Zulkarnain, S.H., Zawawi, E.M.A., Rahman M.Y.A., \& Mustafa, N.K.F. (2011). A review of critical success factor in building maintenance management practice for university sector. World Academy of Science, Engineering and Technology, 5(3), 195 199. 